\title{
REPORT ON FOURTEENTH GENERAL MEETING OF THE NATIONAL COUNCIL OF THE SOUTH AFRICAN SOCIETY OF PHYSIOTHERAPY HELD ON 27th \& 28th MARRCH 1981 IN PRETORIA
}

Office Bearers, members of the National Executive Committee, Branch delegates, representatives on $\mathrm{Na}$ tional and International Organisations, members of the Professional Board and various observers attended the 14th National Council Meeting.

Mrs. A. Mathias, Chairman, introduced Professor F. G. Geldenhuys, President of the South African Medical and Dental Council, President of the South African Medical Association and Dean of the Faculty of Medicine, University of Pretoria. In his opening address
Professor Geldenhuys explained the relationship between Medical Council and the Professional Board, and outlined the developments since 1947, when the register was first established. The Board was established in 1972, the scope of the profession gazetted in 1977, the whole country prescribed in 1979 and a Tariffs Committee had just completed its hearing. The President, Mrs. M. Levy, thanked Professor Geldenhuys and then delivered her Presidential address. Mrs. Mathias paid tribute to the memories of Professor $B$. 
Bromilow-Downing, Miss M. Roper, and Mrs. A. Deacon.

The business meeting commenced by noting apologies, confirming proxy votes, establishing number of votes and two-third majority, and outlining procedure. Additional motions, to be taken under General, were tabled and two motions were withdrawn. Two resolutions passed at the 13 th National Council, were ratified, viz. that the S.A. Neurodevelopmental 'Therapy Association be added the list of National Organisations, a representative to be elected later, and that the cost of NEC members away from Headquarters be contributed to on a pro-rata basis by all Branches.

In the Chairman's Report Mrs. Mathias outlined the activities of the N.E.C., the implementation of resolutions from the I3th National Council Meeting and matters that arose from the Professional Board. Miss E. Botting, Acting General Treasurer, submitted her Report from the Finance Committee and the 1979/80 Financial Statements and 1980/81 Financial Estimates were adopted. Arising from this, annual subscriptions for Full Practising members were raised to R25 (olher categories to be adjusted accordingly), N.E.C. was empowered to consult professional advisers to formulate financial projections for the growth of the Society and the limit for travelling expenses of N.E.C. members was set at R3 000 for the forthcoming term.

The Editorial Board Report was presented by Mrs. Gilder and a set of bound Journals handed to the Chairman. Miss Chatterton, Journal Treasurer, presented the Journal Fund Statements and Estimates, which were adopted. Due to increased costs ol printing and paper, an increased allocation was requested and it was agreed that the incoming N.E.C. will finalise this. Thereafter Miss P. Blake, Appointments Information Secretary, gave her report.

Mrs. Lennard, Chairman of the Activations Sub Committee, outlined the various projects in which the Committee was involved during 1979/80 and suggested that an Action Committee, with wider national representation be established.

The Constitution Sub-Committee had been through the Constitution and made the necessary alterations. Several resclutions were passed, dealing with matters such as defining Physiotherapist/Physical Therapist, Groups and various categories of membership, establishing Standing Committees of N.E.C. (Editorial Board, Finance Committee and Registration Conmittee) and Sub-Committees and Ad Hoc Committees of N.E.C.; the composition of the National Committee of Representatives; ethical rules; and constitutions of Special Groups/Assoziation. The Rezistration Committee assesses applicants and makes recommendations regarding registration, the main problem being the variable practical standards. New application forms are to be drawn up.

The Ad Hoc Committee on Industrial/Occupational Physiotherapy recommended that this be introduced at undergraduate level and suggested Mr. Hayne and Miss McPhee as possible speakers for a lecture tour. It was also suggested that slide-tapes on ergonomics be produced. The Committee for the International Year of Disabled Persons reported on various activities at local and national level that had taken place or were planned. The Investigating Committee had looked into criteria and guidelines for recognition of additional registrable qualifications, optimal physiotherapy case loads in different hospitals and awarding certificates of advanced clinical competence, as well as having supplied information for the memorandum submitted to the Commission of Enquiry into Health Services. The Committee on Medical Referrals drew up a memorandum to suppor1 the suggested change of Rule 21 (Government Gazette RI838 of September 1977) which was sub. mitted to the Professional Board and the Medical Association of South Africa. MASA did not support the suggested change and the Professional Board suggested clifferent wording, viz. ". . . the treatment of any patient unless that patient has been referred by a registered medical practitioner or a registered dentist, or in close co-operation with such registered practitioner, except in an emergency." This was referred back to the incoming N.E.C. for further action.

Special Groups/Associations reported on their activities. The Lecturers Group had revised minimal standards for degree and diploma courses; looked into registrable additional qualifications, educational objectives lor teacher training in physiotherapy and syllabi for training of physiotherapy assistants; organised workshops, put out a quarterly Newsletter and surveyed continuing education priorities in physiotherapy. The Manipulative Therapists Group reported 67 participants in the 75 hour courses in 1979 and 1980 and 28 in the I month course by Mr. Maitland. Members attended the IFOMT Congress and a paper was read. The University of Stellenbosch plans to institute an Honours degree in manipulative therapy. The National Hospital Group now has branches in Transvaal, Natal and the Cape. Two very successful seminars on Management and Marketing were offered in 1980 and 1981. A resolution rescinding the title "Departmental Aides" and reaccepting the title "Physiotherapy Assistants" was carried. The Obstetric Association had been active in sending out regular Newsletters, organising courses, lectures and preparing exercises for a booklet on "baby's first year". The Private Practitioners Association had been involved in the principle of incorporation (not agreed to), Ethical Rule J45 8(a) (medical referral) and the Tariffs Commission; higher group insurance for private practitioners awaits implementation and charge carcis may now be accepted.

Representatives on National Organisations detailed vari-us activit es in which physiotherapists participated. It was noted that 1982 will be the International Year of the Ageing and that information about facilities for and services to the aged should be forwarded to N.E.C. Branch reports and Financial Statements were circulated with the agenda, taken as read and aclopted. It was agreed that Branches requesting exempticn from auditing of their Financial Statements, should forward thei] reasons with their request to N.E.C.

A further motion amended the bye-laws to the effect that the Society shall contribute towards authorised expenses of representatives on National or International Bodies, the amount to be determined by funds available. It was agreed that negotiations.be set up to establish an exchange of physiotherapists between countries for lurtherance of protessional knowledge, experience, and specialisation. The Society was also requested to investigate the appointment of District Physiotherapists by the Department of Health in order to cater for patients referred by District Surgeons in rural areas.

Additional motions dealt with a request to investigate examination results and the withdrawal ol examiners' services; the appointment of an Action Committee, with wide national representation, to be merged with the Activations Committee. Arising from the Chairman's Report the proposed evaluation of the profession of Physiotherapy by the office of the Commission of Administration, was discussed and its importance stressed. A lengthy questionnaire, dealing with description of the profession (to be updated), work situations and work conditions will be used. The incoming N.E.C. was requested to investigate co-ordination of research at undergraduate and postgraduate levels.

Elections then took place and the following were elected:

Honorary Life President: Mr. I. J. Craig. 
Honorary Vice Presidents: Professor E. G. M. Boes (Pretoria); Professor J. C. de Villiers (Cape Town); General N. J. Nieuwoud (Pretoria); Professor F. P. Retief (Medunsa); Dr. D. P. van Velden (Bloemfontein).

Honorary Life Members: Miss G. H. Jones; Miss H. Baines; Miss J. Blair (Lecturers Group); Mr. A. Rothberg (National Hospital Group).

Office Bearers: President: Mrs. K. M. Levy; Chairman: Mrs. A. Mathias; 1st Vice Chairman: Miss S. H. Irwin-Carruthers; 2nd Vice Chairman: Mrs. J. C. Beenhakker; Journal Editor: Mrs. J. A. C. Gilder; General Treasurer: Mrs. B. J. Victor; General Secretary: Referred back to N.E.C.

National Executive Committee: Mr. A. M. Blom; Mrs. F. M. Glauber; Mrs. L. Hack; Mrs. A. McFarlane; Miss E. Smith; Mrs. Y. L. van der Watt.

Representatives on National/International Organisa-

\section{THE SOUTH AFRICAN MEDICAL AND DENTAL COUNCIL \\ THE PROFESSIONAL BOARD FOR PHYSIOTHER APY \\ IMPORTANT NOTICE TO ALL PHYSIOTHERAPISTS}

The attention of all physiotherapists is invited to the rules specifying the acts or omissions in respect of which disciplinary steps may be taken by the Professional Board for Physiotherapy and the Council (Government Notice R1838) and in particular to rule 8(3) thereof, which states that the following is not permissible:

"Undertaking any physiotherapy for or on behalf of any person other than a registered physiotherapist, a medical practitioner against whose name the speciality physical medicine is registered, be it as an employee or in any form of partnership, for gain or for favour, even if referred by a registered medical practitioner or a registered dentist: Provided that this rule shall not apply to any hospital or institution conducted or subsidised by the State or a provincial or local authority or by the South African Chamber of Mines or such other institution or medical practitioners as may be approved for the purpose by the professional board and the council."

A number of employing authorities have already been so approved.

This notice is sent out at the request of the Professional Board for Physiotherapy and serves as an invitation to physiotherapists who are employed by institutions which have not been approved by the Professional Board to apply for approval to place their practice on a sound ethical footing and thereby to obviate the possibility of disciplinary proceedings in the future should complaints be lodged with the Professional Board.

Physiotherapists who are currently practising in South Africa contrary to ethical rule 8(3) quoted above and who respond to this notice may rest assured that no disciplinary steps will be taken by the Professional Board following such response. Kindly write to: The Registrar, SA Medical and Dental Council, P.O. Box 205, Pretoria, 0001, and furnish full particulars of your current work situation and the name of the employer.

An appeal is made to physiotherapists to disseminate the information in this notice as widely as possible, especially to employing institutions who have in the past, or are currently, or seem likely in the future to be, employing physiotherapists contrary to rule $8(3)$.

Thank you for your co-operation.

N. M. PRINSLOO,

Registrar.

JUNE 1981. tions: National Council for the Care of Cripples: Miss K. Brinkworth; National Council of Women in South Africa: Mrs. J. Utermöhlen; South African National Council for the Aged: Mrs. A. Stewart; South African National Council for Health Education: Mrs. M. Kvasz; South African Neurodevelopment Therapy Association: Miss S. H. Irwin-Carruthers; World Confederation for Physical Therapy: Miss P. Bowerbank.

The next Council Meeting will be held in Bloemfontein in 1983.

\section{REPORT ON EMERGENCY COUNCIL MEETING HELD IN JOHANNESBURG ON 13th JUNE 1981}

The motion dealing with the withdrawal of examiners' services from the Department of National Education was rescinded after lengthy discussion and an amended motion was carried.

\section{DIE SUID-AFRIKAANSE GENEESKUNDIGE EN TANDHEELKUNDIGE RAAD DIE BEROEPSRAAD VIR FISIOTERAPIE BELANGRIKE KENNISGEWING AAN ALLE FISIOTERA PEUTE}

Die aandag van alle fisioterapeute word gevestig op die reêls wat die handelinge of versuime uiteensit ten opsigte waarvan tugstappe deur die Beroepsraad vir Fisioterapie en die Raad gedoen kan word (Goewermentskennisgewing $R 1838$ ) met spesifieke verwysing na reël 8(3), wat die volgende as ontoelaatbaar stel:

"Enige fisioterapiewerk verrig vir of namens enige persoon behalwe vir 'n geregistreerde fisioterapeut, 'n geneesheer teen wie se naam die spesialiteit fisiese geneeskunde geregistreer is, hetsy as 'n werknemer of in enige vorm van vennootskap, vir wins of vir guns, selfs al is sodanige werk deur ' $n$ geregistreerde geneesheer of tandarts verwys: Met dien verstande dat hierdie reël nie van toepassing is nie op enige hospitaal of inrigting wat beheer of gesubsidieer word deur die Staat of 'n provinsiale of plaaslike owerheid of deur die Kamer van Mynwese van Suid-Afrika, of sodanige ander inrigting of geneeshere as wat vir die doel deur die beroepsraad en die raad goedgekeur mag word."

Etlike indiensnemingsowerhede is alreeds so goedgekeur.

Hierdie kennisgewing word uitgestuur op versoek van die Beroepsraad vir Fisioterapie en dien as 'n uitnodiging aan fisioterapeute wat in diens staan van instansies wat nog nie deur die Beroepsraad goedgekeur is nie om aansoek te doen vir goedkeuring, ten einde hul praktyk op 'n gesonde etiese grondslag te plaas en daardeur die moontlikheid van dissiplinère stappe in die toekoms te vermy, indien klagtes by die Beroepsraad gelê sou word.

Fisioterapeute wat tans in Suid-Afrika strydig met etiese reël $8(3)$ hierbo aangehaal praktiseer en wat op hierdie kennisgewing reageer kan gerus wees dat geen dissiplinêre stappe deur die Beroepsraad geneem sal word in opvolging van sodanige reaksie nie. Skryf asseblief aan: Die Registrateur, SA Geneeskundige en Tandheelkundige Raad, Posbus 205, Pretoria, 0001, en verskaf volledige besonderhede van " huidige werksituasie en die naam van u werkgewer.

in Beroep word op alle fisioterapeute gedoen om die inhou'] van hierdie kennisgewing so wyd as moontlik bekend te maak, veral onder indiensnemingsowerhede wat in die verlede fisioterapeute in diens geneem het, of wat dit tans doen of wat dit moontlik in die toekoms gaan doen, teenstrydig met die bepalings van reël $8(3)$.

Dankie vir u samewerking.

N. M. PRINSLOO,

Registrateur. 